\title{
Learning Obstacle Analysis of Indonesian Primary Students on Rectangular Concept and Its Alternative Solutions
}

\author{
Aulia Musla Mustika ${ }^{1, *}$, Budiyono $^{2}$, Riyadi $^{2}$ \\ ${ }^{1}$ Universitas Lampung, Lampung, Indonesia. \\ ${ }^{2}$ Universitas Sebelas Maret, Surakarta, Indonesia. \\ *Correspondinge-mail:auliamuslamustika1989@gmail.com
}

Received: 22 Maret 2018

Accepted: 25 April 2018

Published: 30 April 2018

\begin{abstract}
Learning Obstacle Analysis of Indonesian Primary Students on Rectangular Concept and its Altenative Solutions. This study was aimed at analyzing students' learning obstacles and mistakes in mathematical answers on the concept of rectangle. The study involved 28 junior high school students in Surakarta, Central Java, using a quantitative method. Based on the results of data analysis, 5 types of students' learning obstacles based on their answers were identified including variation of information context, concept image, relationship between rectangle's area and its width, student's ability to cope with questions, and relation between one concept to another. The alternative to overcome thelearning obstacles and mistakes in mathematical answers was by applying a didactic design which consisted of lesson plans, students' worksheet as well as prediction of response and didactic anticipation.
\end{abstract}

Keywords:Learning obstacles, mistakes in mathematical answers, didactic design

Abstrak. Analisis Hambatan Belajar pada Siswa SMP di Indonesia pada Konsep Bangun Segi Empat dan Alternatif Penyelesaiannya. Tujuan penelitian ini adalah menganalisis hambatan belajar dan kesalahan jawaban matematika siswa pada konsep bangun segiempat. Penelitian ini melibatkan 28 siswa salah satu Sekolah Menengah Pertama (SMP) diSurakarta, Jawa Tengah, dengan menggunakan metode deskriptif kualitatif. Berdasarkan hasil analisis data, teridentifikasi 5 tipe hambatan belajar berdasarkan indikator kesalahan jawaban matematika siswa yaitu tipe konteks variasi informasi, concept image, hubungan keliling dan luas segiempat, kemampuan siswa dalam menyelesaikan soal-soal, dan koneksi antar konsep. Alternatif untuk mengatasi hambatan belajar yang menyebabkan kesalahan jawaban tersebut, salah satunya yaitu dengan menerapkan desain didaktikyang terdiri dari RPP, lembar kerja siswa serta prediksi respons dan antisipasi didaktik.

Kata Kunci: Hambatan belajar, kesalahan jawaban matematika, desain didaktik 


\section{INTRODUCTION}

Mathematics is one of the primary subjects studied in every level of education, from elementary school, high school, and even college. This indicates that mathematics plays an important role and must be controlled by every individual. It is in line with Syaban (2009) who states that the abilities face their problems, either mathematics or the problems that we face in the real world which is mathematical power.

The involvement of students who are less intensive in learning mathematics can cause students to quickly forget what has been learned. Students are used to listening to teacher explanations, both when introducing formulas and when giving examples, so that the ability to analyze problems with higherdifficulty levels becomes less. The impact, consciously or unconsciously, traditional learning will discourage students from developing their thinking skills.

The goal of mathematics education is to make all students successful (Tall \& Razali, 1993). However, in fact, although some of students get high score in mathematics, the majority of the students show that mathematics is difficult. However, a success can be achieved, but there are still some students who really need help in learning mathematics.

The learning's obstacle is the thing that happens in the learning process that affect the students to get difficulty to understand the materials or they have misunderstanding about their perceptions in their materials. The learning's obstacle in this research is the obstacle which has epistemologist character that depends on the different context where someone only understands a limited material in limited context, so that, when they are faced in the different context they will get some difficulties.

Ciltas \& Taltar (2011) state that the students learning's obstacle in general is: (1) inadequate basic concept of learning, (2) inability to attempt to formulate oral math problems, (3) lack of algebra skills, geometry, and trigonometry. Therefore, the topic under study is a quadrilateral that is part of the geometry.

The students learning' obstacle that happens should be identified. From the identification, it is hoped the teachers are able to makea lesson plan that is able to minimize the students' learning's obstacles. Furthermore, further research is needed to investigate the students' learning obstacles, especially in the material of geometry with a topic of rectangle, and the effort to overcome the learning obstacles.

\section{METHOD}

This research used qualitative descriptive methods. The instrument of this research was a written test which consisted of 8 questions that had been validated and depth-interviewed. Some considerations when deciding to adopt a qualitative research methodology were that qualitative methods can be used to understand any unknown phenomena. Besides that, the method was also able to be used to get deeper information that might be difficult to find out quantitatively, for example, investigating students's ways in answering and predicting what they have learnt and imagined the questions (Strauss dan Corbin, 1990). Thus, through this method, the research problem tended to be framed as an open question that would support the discovery of new information.

\section{RESULTS AND DISCUSSIONS}

The research was conducted to 28 students in one junior high school in Surakarta, Central Java which was grouped into two main parts.

\section{Analysis of Students' Written Test Answers}

The analysis of the answer analysis of 8 written test questions of students class VIII is as follows: 
a) Item number 1

It is known that the two-dimensional figure $\mathrm{ABCD}$ has a length of $\mathrm{AD}=5 \mathrm{~cm}, \mathrm{DE}=4 \mathrm{~cm}$ and $\mathrm{DC}=12 \mathrm{~cm}$. Find out the area.

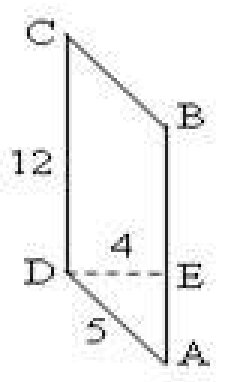

There were only four out of 28 students who were able to answer this question correctly while many other students are fooled by the image. They did not realize that the picture presented is a picture of parallel gram. They were not able to determine the base and height because parallel gram was presented differently from parallelogram known by the students. This was also reinforced by the results of interviews conducted to the students. Based on the textbook that was used as in Nuharini \& Wahyuni (2008) and mathematics learning module as attached, the majority of the questions present images of parallelogram in the following shape.

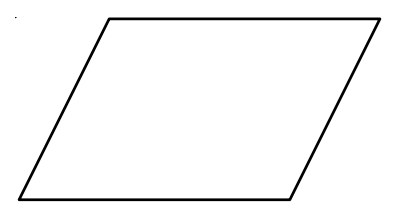

The concept image embedded in the minds of the students about parallelogram is like the picture. Therefore, the students were confused when given a question presenting a different image of parallel gram.

Students were fooled by the excess information on the question, namely the existence of information on lineDA. A total of 15 students answered that the area of the shape was by multiplying CD, DE and AD. It could happen because students were not used to practicing to choose the information provided before solving the question. The textbooks used were less varied.

Table 1. Indicators of competency mastery and obstacles in learning item number 1

\begin{tabular}{|c|c|}
\hline $\begin{array}{c}\text { Indicators of } \\
\text { Competency Mastery }\end{array}$ & $\begin{array}{c}\text { Indicators of Learr } \\
\text { Obstacles }\end{array}$ \\
\hline $\begin{array}{l}\text { Know the } \\
\text { differences and } \\
\text { similarities } \\
\text { between square, } \\
\text { rectangle, } \\
\text { trapezium, } \\
\text { parallelogram, } \\
\text { rhombus and kite } \\
\text { based on sides and } \\
\text { angles }\end{array}$ & $\begin{array}{l}\text { Students cannot } \\
\text { determine the base } \\
\text { height or any other } \\
\text { components in the } \\
\text { quadrilateral show } \\
\text { the question when } \\
\text { shape is presented } \\
\text { differently from th } \\
\text { shape commonly } \\
\text { known by the stude }\end{array}$ \\
\hline $\begin{array}{l}\text { Understand how to } \\
\text { calculate the area } \\
\text { of a rectangle, } \\
\text { square, trapezoid, } \\
\text { parallelogram, } \\
\text { rhombus, and kite. }\end{array}$ & $\begin{array}{l}\text { Students are foole } \\
\text { the excess informa } \\
\text { in the question }\end{array}$ \\
\hline
\end{tabular}

According to the argument of contrast and diversity in Bruner's theory (Suherman, et al, 2003), it was stated that in mathematics learning should use examples and non-examples and various variations, so that theconcept understanding becomes more stable. Students can choose what is included and not included in the concept, and they can show more examples for the concept as an application.

b) Item Number 2

Mention the similarities and the differences between the two figures below ifviewed from the sides, angles, and diagonals! 


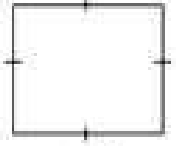

(a)

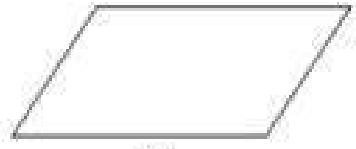

(b)
Table 2. Indicators of competence mastery and learning obstacles of item number 2

\begin{tabular}{ll}
\hline \multicolumn{1}{c}{$\begin{array}{c}\text { Indicators of } \\
\text { Competence Mastery }\end{array}$} & $\begin{array}{l}\text { Indicators of } \\
\text { Learning Obstacles }\end{array}$ \\
\hline $\begin{array}{l}\text { Know the } \\
\text { characteristics of a } \\
\text { rectangle, square, } \\
\text { trapezoid, } \\
\text { parallelogram, } \\
\text { rhombus and kite. }\end{array}$ & $\begin{array}{l}\text { Students cannot } \\
\text { express the } \\
\text { names of flat } \\
\text { shapes and their } \\
\text { properties and } \\
\text { their } \\
\text { relationships } \\
\text { with the other } \\
\text { rectangular flat } \\
\text { shapes. }\end{array}$ \\
$\begin{array}{l}\text { Know the } \\
\text { differences and } \\
\text { similarities between } \\
\text { rectangles, squares, } \\
\text { trapezoids, } \\
\text { parallelogram, } \\
\text { diamonds and kites } \\
\text { according to side } \\
\text { and angle. }\end{array}$ & \\
\hline
\end{tabular}

From the 28 students, none of them is able to mention the similarities and differences of the two figures above in a complete detail from the points of view of side, angle, and diagonal. Students only answer the similarities and differences between the two figures by looking at either the sides or angles or diagonals but not looking at the three of them. The results of the interview also indicate that it is difficult for them to express what is in their mind. Most of thethem mention the characteristics of the figures based on what they see in the figures, not because of their properties. This is indicated by the overall students' answers which are not yet specific.

This item is related to Van Hiele's level. The students come from lower cluster school falls into the Van Hiele level 1. The students know the properties of a rectangle but have not been able to explore more deeply (still influenced by the level 0 of Van Hiele that is looking at a shape based on what appears and the ability to analyze is still limited). The ability to communicate and express ideas is also still lacking. Thus, it is necessary to provide a learning that can raise the level of Van Hiele effectively to help overcome the learning obstacles that may occur.

Here are the variety of students' answers.

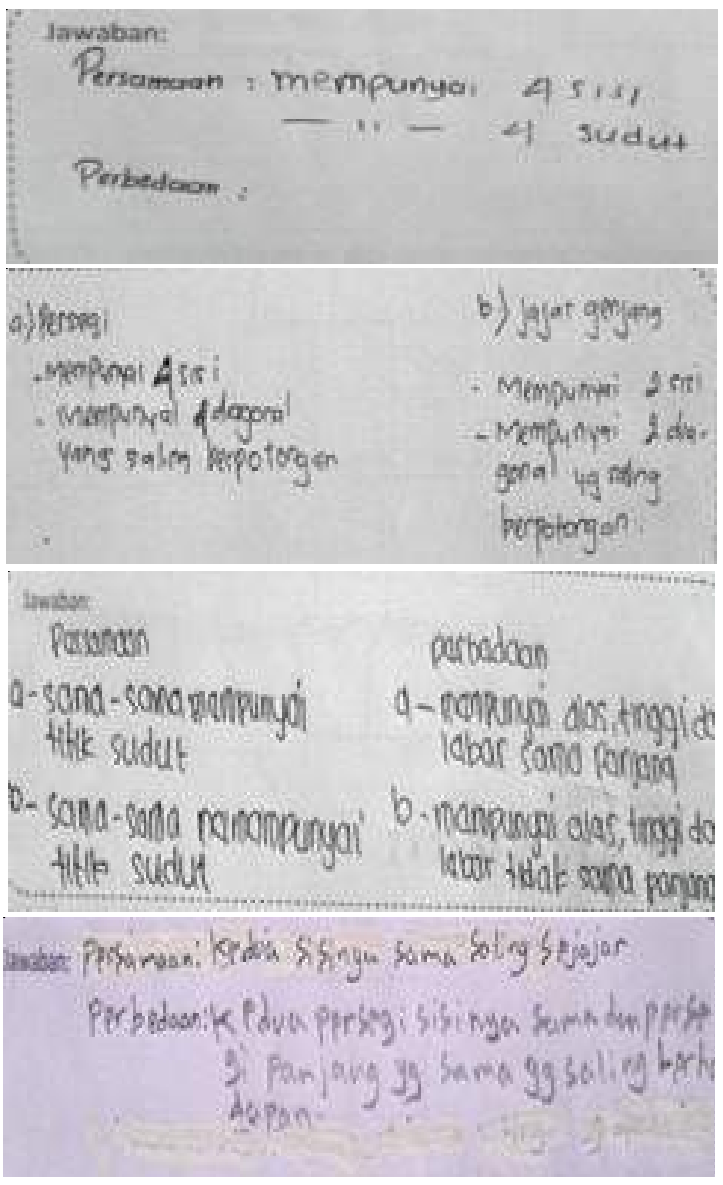

Figure 1. Variety of students' answers of lass III D of item number 2

c) Item Number 3

Take a look at both shapes A and $\mathrm{B}$ below! If the length of the base side, the upper side, and the height of the two shapes are the same. Is the circumference of the two shapes the same? 
Explain your reasons! Is the area of both shapes the same? Explain your reasons!
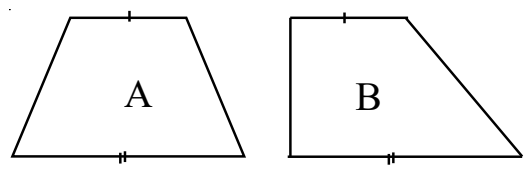

None of the students is able to answer both questions correctly and with the right reasons. Students who are able to answer item 3 a correctly do not necessarily answer item $3 \mathrm{~b}$ correctly, and vice versa. The reasons stated by the students are not yet in accordance with the concept of circumference and the area of trapezoid. The results of the interviews show that students have notbeen able to distinguish between circumference and area firmly. This causes most students to answer questions $a$ and $b$ with the same answer, whereas the concept of circumference and area is much different.

Table 3. Indicators of competence mastery and learning obstacles of item number 3

\begin{tabular}{ll}
\hline $\begin{array}{l}\text { Indicators of } \\
\text { Achievement } \\
\text { Mastery }\end{array}$ & $\begin{array}{l}\text { Indicators of } \\
\text { Learning Obstacles }\end{array}$ \\
\hline $\begin{array}{l}\text { Able to cope with } \\
\text { problems related to } \\
\text { circumferenceof a } \\
\text { rectangle, square, } \\
\text { trapezoid, }\end{array}$ & $\begin{array}{l}\text { Students cannot } \\
\text { determine the } \\
\text { relationship } \\
\text { between the } \\
\text { circullelogram, } \\
\text { rhombus and kite }\end{array}$ \\
$\begin{array}{l}\text { one rectangle and } \\
\text { another without } \\
\text { information of } \\
\text { numbers in the }\end{array}$ \\
$\begin{array}{l}\text { Able to cope with } \\
\text { problems related to }\end{array}$ & $\begin{array}{l}\text { Students cannot } \\
\text { determine the } \\
\text { the area of }\end{array}$ \\
$\begin{array}{l}\text { relationship } \\
\text { rectangles, squares, } \\
\text { trapezoids, }\end{array}$ & $\begin{array}{l}\text { between the area of } \\
\text { a rectangle and } \\
\text { diamollogram, }\end{array}$ \\
$\begin{array}{l}\text { another without } \\
\text { according to side } \\
\text { and angle. }\end{array}$ & $\begin{array}{l}\text { information of } \\
\text { numbers in the }\end{array}$ \\
\hline
\end{tabular}

Here are the students' incorrect answers. The various answers indicate the variety of mistakes that appear. The figures below represent the answers of other students.

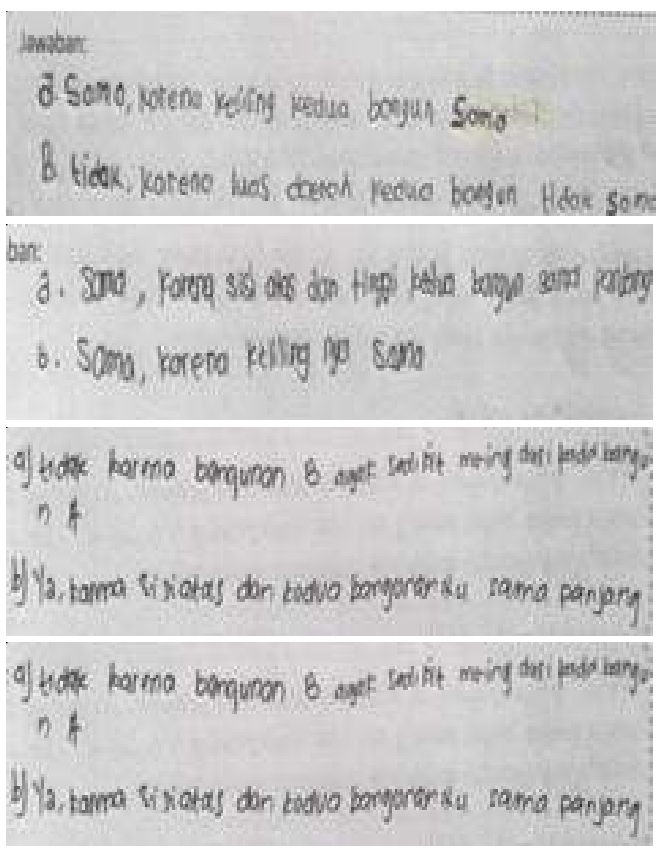

Figure 2. Variety of students' answers class III D item number 3

The exercise questions that they have gone through so far always present numerical information. In the textbooks and learning modules used, none of the questions related to concepts is without numerical information. Therefore, students find it difficult if faced with conceptual problems.

d) Item Number 4

Look at the rhombus and kite figures below! If the circumference of the rhombus is the same as the circumference of the kite, then how long is the side of the rhombus?
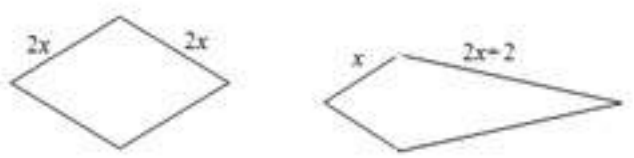
Table 4. Indicators of competence mastery and learning obstacles of item number 4

\begin{tabular}{ll}
\hline \multicolumn{1}{c}{$\begin{array}{c}\text { Indicator of } \\
\text { Competence } \\
\text { Mastery }\end{array}$} & $\begin{array}{c}\text { Indicator of } \\
\text { Learning } \\
\text { Obstacles }\end{array}$ \\
\hline $\begin{array}{l}\text { Understand how } \\
\text { to calculate the } \\
\text { circumference of } \\
\text { rectangles, }\end{array}$ & $\begin{array}{l}\text { Cannot solve a } \\
\text { problem about } \\
\text { rectangular } \\
\text { circumference } \\
\text { trapezoids, } \\
\text { parallelogram, } \\
\text { rhombus and }\end{array}$ \\
kite. & $\begin{array}{l}\text { associated with } \\
\text { other } \\
\text { mathematical } \\
\text { concepts. }\end{array}$ \\
\hline
\end{tabular}

This question is only answered by five students with an incomplete answer. Five students who answer this question have not been able to solve the equations in algebraic form correctly. This shows that students' understanding of algebraic material is not strong enough. Students that have not been able to identify that algebra is known to be representative of the length of the rhombus and kite's sides. The concept of circumference has not been mastered by students well. When interviewed, the students admitted to have answered this question with the original answer because the students did not understand what was meant in the question. Furthermore, the students have not mastered doing algebraic calculations yet, even simple calculations like, " $2 x$ plus $2 x$ ". New students can answer when there is an analogy, "How many do you get when two chickens are added by other two chickens"

Here is the variety of the students' answers.

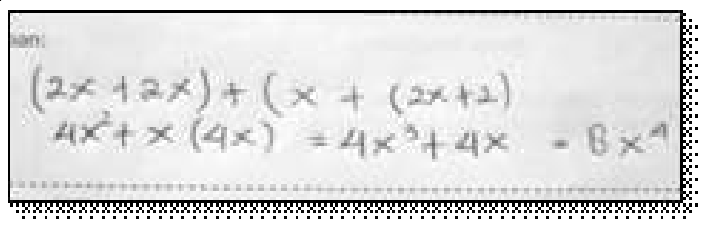

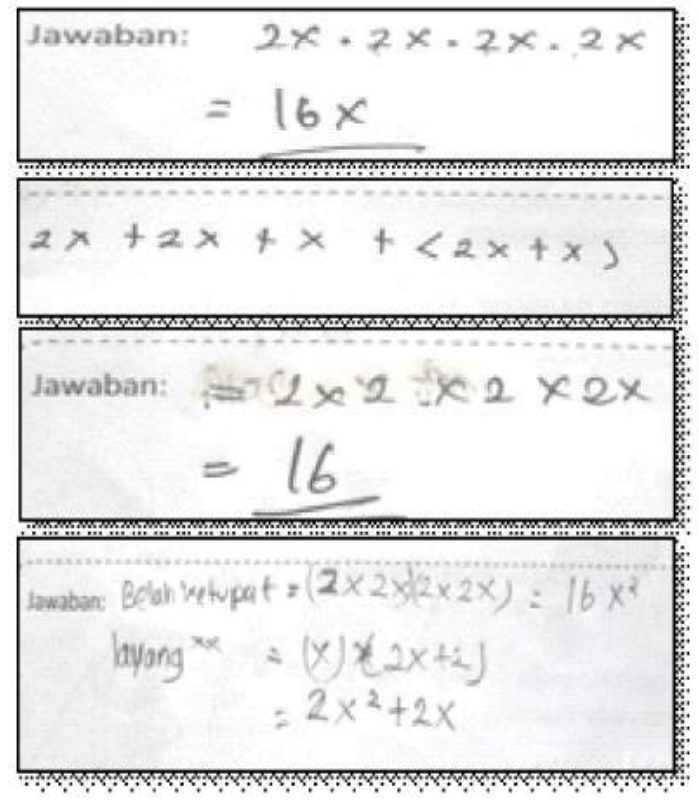

Figure 3. Variety of students' answers of class VIII D item number 4

e) Item Number 5

Dad buys a piece of a rectangle-shaped land with a length of $30 \mathrm{~m}$ and a width of $20 \mathrm{~m}$. If the price of each $\mathrm{m} 2$ of the land is $\mathrm{Rp} 50,000.00$ then how much money does father haveto pay to buy the land?

A total of 16 students managed to answer this question correctly, while the other some made a mistake in calculating the area of the rectangle (a plot of land). Students make a mistake of summing the length and width of the rectangle to measure its area, not by multiplying the length and width. But when asked to re-examine the answer, the student admits to have miscalculated and should have multiplied the length and width of the shape instead of summing it up. Similarly, the error of inclusion of units also occurr. Students who are reminded of the unit area can immediately correct that the mistake is to include meters as units of area, not square meters. Therefore, students need to be strengthened again about the concept of the area of the quadrilateral area and to be more thorough to include a unit. 
Table 5. Indicator of competence mastery and learning obstacles of item number 5

\begin{tabular}{ll}
\hline $\begin{array}{c}\text { Indicator of } \\
\text { Competence Mastery }\end{array}$ & $\begin{array}{c}\text { Indicator of Learning } \\
\text { Obstacles }\end{array}$ \\
\hline $\begin{array}{l}\text { Understand how to } \\
\text { calculate the area } \\
\text { of rectangle, } \\
\text { square, trapezoid, } \\
\text { parallelogram, } \\
\text { rhombus and kite. }\end{array}$ & $\begin{array}{l}\text { Cannot solve the } \\
\text { question related to } \\
\text { the area of the } \\
\text { quadrilateral } \\
\text { associated with } \\
\text { other mathematical } \\
\text { concepts. }\end{array}$ \\
$\begin{array}{l}\text { Able to solve } \\
\text { problems related to } \\
\text { the area of } \\
\text { rectangle, square, } \\
\text { trapezoid, } \\
\text { parallelogram, } \\
\text { rhombus and kite }\end{array}$ \\
\hline
\end{tabular}

Here is an example of a wrong student's answer. Another student's mistake lies only in the incomplete inclusion of a unit area.

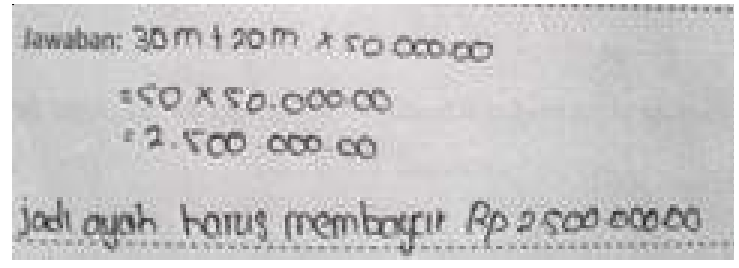

Figure 4. Example of students' incorrect answer of class VIII D item number 5

\section{f) Item Number 6}

Here are figures of three congruent squares of which each of its side length is five $\mathrm{cm}$. Please measure the circumference!

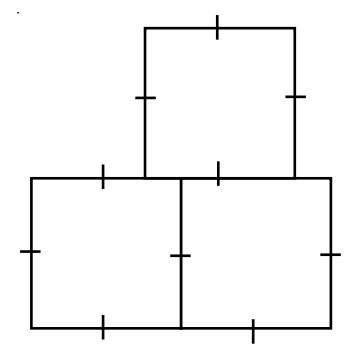

Table 6. Indicator of competence mastery and learning obstacles of item number 6

\begin{tabular}{ll}
\hline $\begin{array}{l}\text { Indicator of } \\
\text { Competence Mastery }\end{array}$ & $\begin{array}{l}\text { Indicator of } \\
\text { Learning } \\
\text { Obstacles }\end{array}$ \\
\hline $\begin{array}{l}\text { Understand the } \\
\text { way of measuring } \\
\text { the circumference } \\
\text { of rectangle, } \\
\text { square, trapezoid, } \\
\text { parallelogram, } \\
\text { rhombus and kite. }\end{array}$ & $\begin{array}{l}\text { Cannot solve } \\
\text { about square } \\
\text { that should be } \\
\text { constructed } \\
\text { first. }\end{array}$ \\
$\begin{array}{l}\text { Able to solve } \\
\text { problems related } \\
\text { to the } \\
\text { circumference of } \\
\text { rectangle, square, } \\
\text { trapezoid, } \\
\text { parallelogram, } \\
\text { rhombus and kite. }\end{array}$ \\
\hline
\end{tabular}

Seven students answered this question correctly while the other had trouble in determining the circumference of the figure because there was no information on numbers on the side coinciding. This issue requires students to construct the figures first before completion, but most students are not able to construct them. The students have not mastered the concept of circumference well. This can be seen from students'answers that add up the entire length of the sides, including the sides of each other. Another student error lies in using a circumference formula, i.e. the student multiplies the length of the known side, rather than summing it up. This is reinforced by interviews.

Here is the variety of students' answers.

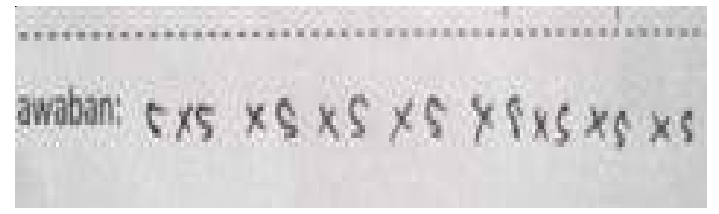




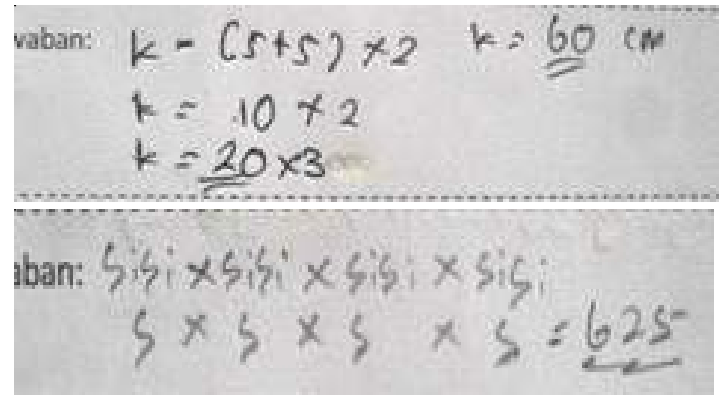

Figure 5. Varietyof students' answers of classVIII Ditem number 6

Thus, reinforcement on the concept of square circumference and the ability to analyze the information of the item is needed.

\section{g) Item Number 7}

There is a room in a rectangular shape. Along the long side floor of the room, ten tiles are fitted on the floor, and the other short side is fitted with eight tiles. If the area of one tile is 9 $\mathrm{m}^{2}$, how is the total area of the floor in the room? Table 7. Indicators of competence mastery and lkearning obstacles of item number 7

\begin{tabular}{ll}
\hline \multicolumn{1}{c}{$\begin{array}{c}\text { Indicator of } \\
\text { Competence } \\
\text { Achievement }\end{array}$} & $\begin{array}{l}\text { Indicator of } \\
\text { Learning } \\
\text { Obstacles }\end{array}$ \\
\hline $\begin{array}{l}\text { Understand the way } \\
\text { of measuring the area } \\
\text { of rectangle, square, } \\
\text { trapezoid, }\end{array}$ & $\begin{array}{l}\text { Cannot solve a } \\
\text { problem about } \\
\text { parallelogram, } \\
\text { square that } \\
\text { should be } \\
\text { constructed } \\
\text { first. }\end{array}$ \\
$\begin{array}{l}\text { Able to solve } \\
\text { problems related to } \\
\text { the area of rectangle, }\end{array}$ & \\
square, trapezoid, \\
parallelogram, \\
rhombus and kite
\end{tabular}

This questions is a simple questions that requires students' accuracy in analyzing the information that exists on the item. However, only three students were able to answer the question correctly, while the other students made a mistake in counting the number of tiles on the floor. Mistakes that occur vary andbased on these errors it can be seen that students are not able to process the information on the question and connect it with the concept of rectangulararea to solve the problem.

Here is the variety of students' answers.

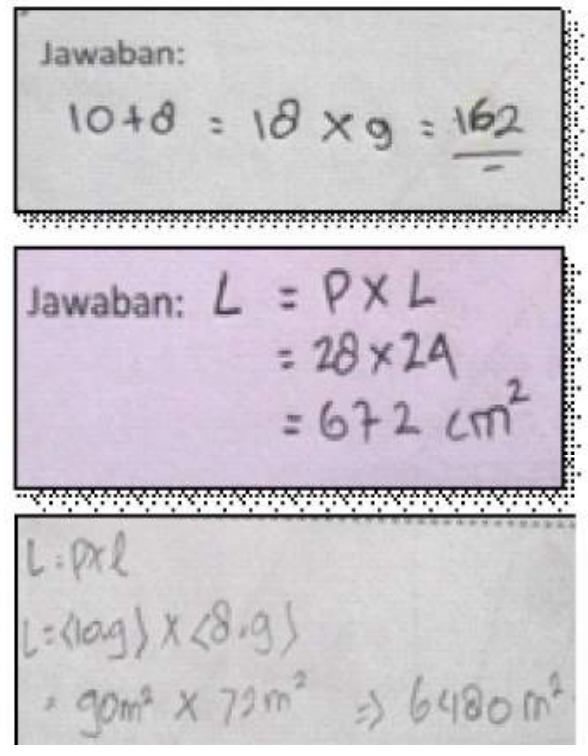

Figure 6. Variety of students' answers of classVIII Ditem number 7

\section{h) Item Number 8}

In the surrounding of Mrs. Aulia's house, it will be planted some roses. If the home yard is in the shape of rectangle with the length of $5 \mathrm{~m}$ and width of $3 \mathrm{~m}$, how many roses are needed if the distance of each rose plant is $50 \mathrm{~cm}$ ?

This question is a question related to the concept of circumference. However, most students answered the question by using the concept of a rectangular area and only two students were able to answer correctly. Another mistake that occurs is that the students do not change the unit of meter into centimeters in the calculation. 
Here is the variety of students' answers.

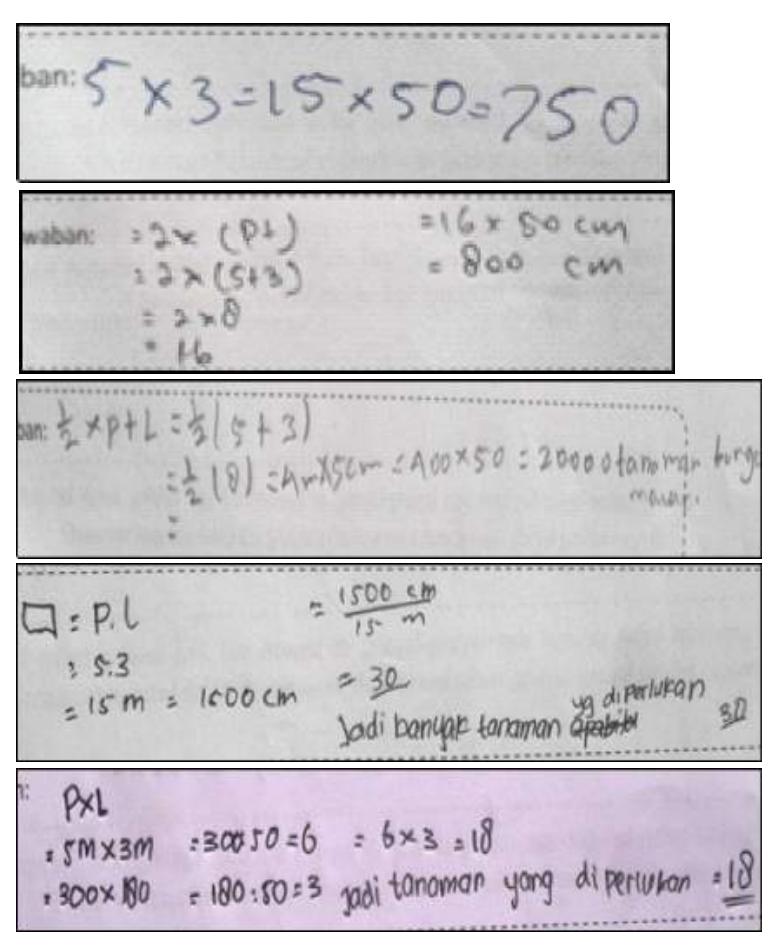

Figure 7. Variety of students' answers of class VIII D item number 8

Table 8. Indicator of competence mastery and learning obstacles of item number 8

\begin{tabular}{|c|c|}
\hline $\begin{array}{c}\text { Indicator of } \\
\text { Competence Mastery }\end{array}$ & $\begin{array}{c}\text { Indicator of } \\
\text { Learning Obstacles }\end{array}$ \\
\hline $\begin{array}{l}\text { Understand the } \\
\text { way of measuring } \\
\text { the circumference } \\
\text { of rectangle, } \\
\text { square, trapezoid, } \\
\text { parallelogram, } \\
\text { rhombus and kite. }\end{array}$ & $\begin{array}{l}\text { Cannot solve a } \\
\text { problem about } \\
\text { the circumference } \\
\text { of square. }\end{array}$ \\
\hline $\begin{array}{l}\text { Able to solve } \\
\text { problems related } \\
\text { to the circum- } \\
\text { ference of } \\
\text { rectangle, square, } \\
\text { trapezoid, } \\
\text { parallelogram, } \\
\text { rhombus and kite. }\end{array}$ & \\
\hline
\end{tabular}

This results suggests that students need reinforcement about the concept of the square and the area of the quadrilateral and the differences between the two concepts, as well as the accuracy in calculating and listing the units, although when re-asked and asked to re-examine the answer, the students know where the mistake lies. Students are not accustomed to visualize the information contained in the question. When answering the question, the students immediately try to calculate, whereas the more effective step is the students first create a drawing to facilitate the workmanship of the question.

The recapitulation of students' correct and incorrect answers percentage was shown in Figure 8.

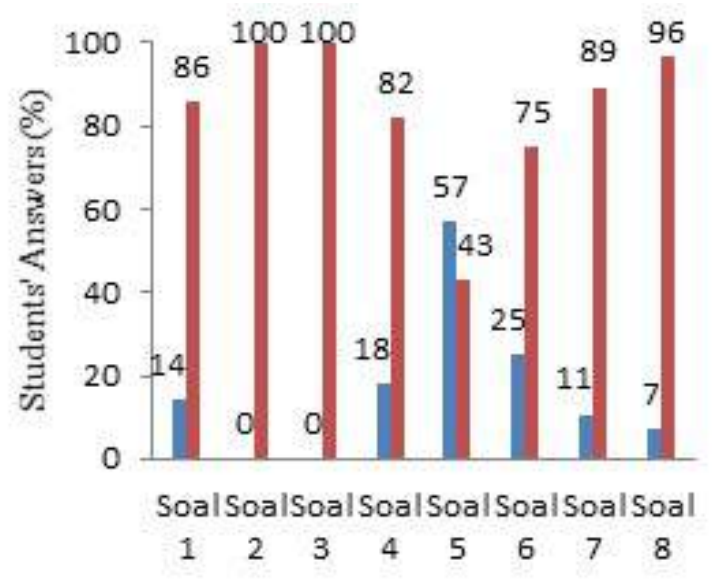

Figure 8. The Recapitulation of students' answers correct (blue); uncorrect (red)

\section{Alternative Diagnosis Solution of Students' Learning Obstacles}

Several indicators of students' learning obstacles require alternatives to overcome or minimize their learning difficulties in mathematics subjects, especially on the concept of shapes. Based on previous descriptions, some students learning obstacles show that students have not been able to: a) determine the components in the quadrilateral when the shapes are presented differently from the shapes thatthey have already 
known, b) look for the relationship between one variable and the other without the numbers on the question, c) resolve questions about rectangular circumference associated with other mathematical concepts, d) solve quadrilateral problems that must be constructed first. The indicators indicate that there are five types of students 'mathematics learning obstacles: context of information variation, concept image, relationship between circumference and areaof a square, students' ability to solve problems, and connections between concepts.

An alternative solution that can be done is to develop a didactic approach in the form of tools or learning media to facilitate students' understanding of mathematical concepts, so that students are able to solve the form of mathematical questions that develop over time. This is based on the reason that the didactic approach or method can improve students' understanding of the modification of mathematical questions (Verschaffel, et al., 2000) and the quality of mathematics learning (Simon, \& Tzur, 2004). In general, the definition of didactic term is teaching. Warfild (2006) defines didactic through Guy Brousseau's research experience as something related to knowledge, the relationship of that knowledge to other knowledge, the students who study it, the learning objectives, and the theoretical and practical conditions of pedagogical activities in learning. In other words, didactic is an attempt by the teacher to make the students interact with the knowledge material more easily and understand the concepts given well.

Meanwhile, according to Ruthven (2009), didactic design is a design of the learning environment and the order of teaching informed through the analysis of specific topics of concern and framing within a particular subject area. The main purpose of the design is to design a teaching sequence that is not only suitable for widespread use in ordinary class circumstances but is sufficiently comprehensive and robust to achieve the desired effect in a reliable manner. The use of didactic methods in a learning model is able to explore students' mathematical understanding (Van Den Heuvel-Panhuizen, 2003).

\section{CONCLUSION}

Based on the data analyses, a conclusion can be drawn that there are 5 types of obstacles to learn mathematics based on the indicators of student's mathematical answers which include the types of context variation of information, concept image, relationships between area and circumference, students' ability in solving problems, and connections between concepts. Based on the analysis of the incorrect responses and the types of learning obstacles that arise, the appropriate alternative learning design is to solve the problem throughthe implementation of a didactic design.

\section{REFFERENCES}

Ciltas, A. \& Tatar, E. (2011). Diagnosing Learning Difficulties Related to the Equation and Inequality that Contain Terms with Absolute Value. International Online Journal of Educational Sciences, 3(2), 461-473

Nuharini, D. \& Wahyuni, T. (2008). Matematika Konsep dan Aplikasinya untuk VII SMP dan MTs. Surakarta: Departemen Pendidikan Nasional.

Ruthven, K. (2009). Design Tools in Didactical Research: Instrumenting the Epistemological and Cognitive Aspects of the Design of Teaching Sequences. Educational Researcher, 38, 329.

Simon, M. A., \& Tzur, R. (2004). Explicating the role of mathematical tasks in conceptual learning: An elaboration of the hypothetical learning trajectory. Mathematical thinking and learning, 6(2), 91-104. 
Strauss, A., \& Corbin, J. (1990). Basics of qualitative research: Grounded theory procedures and techniques. Newbury Park, CA: Sage Publications, Inc.

Suherman, E., Herman, T., Nurjanah, Prabawanto, S., Suryadi, D., Suherman, Rohayati, A., Turmudi. (2003). Strategi Pembelajaran Matematika Kontemporer. Bandung: FPMIPAUPI.

Syaban. 2009. Menumbuh kembangkan Daya dan Disposisi Matematis Siswa Sekolah Menengah Atas melalui Pembelajaran Investigasi. Educationist, 3(2), 129-136.

Tall, D. \& Razali, M.R. (1993). Diagnosing students' difficulties in learning mathematics. International Journal of Mathematical Education in Science and Technology, Vol.24 (No.2). pp. 209222.

Van Den Heuvel-Panhuizen, M. (2003). The didactical use of models in realistic mathematics education: An example from a longitudinal trajectory on percentage. Educational studies in Mathematics, 54(1), 9-35.

Verschaffel, L., Greer, B., \& De Corte, E. (2000). Making sense of word problems. Lisse, The.

Warfield, V.A. (2006). Invitation to Didactique. University of Washington. 